\title{
Index of Manuscripts
}

Bamberg,

Staatsbibliothek

E III 22

315; 317; 317 n.10

Città del Vaticano,

Biblioteca Apostolica Vaticana

Pal. Lat. 24

$92 ; 102 ; 343$

Firenze,

Biblioteca Medicea Laurenziana

Laurentianus 68.166 n.65

Parigi,

Bibliothèque Nationale de France

Lat. 5730 , f. 225 v. 65 n. 65 
